\title{
Corporate Affiliations and the (Mis)Allocation of Credit
}

\author{
Joe Peek and Eric S. Rosengren*
}

\begin{abstract}
The strong corporate affiliations in Japan have been cited as one of the major impediments to making the fundamental changes necessary to escape the economic malaise that has afflicted the Japanese economy over the past decade. While Japanese corporate affiliations during good economic times were heralded as an effective way to increase credit availability and reduce agency costs, during difficult economic circumstances these same affiliations may impede needed economic restructuring, insofar as they insulate firms from the market discipline that otherwise would be imposed by creditors. This paper shows that corporate affiliations have contributed to significant misallocations of credit, since troubled borrowers with strong corporate affiliations with their lenders are more likely to obtain additional credit than their healthier brethren. In contrast, lenders that are not affiliated with the firm are much less likely to extend additional credit as firms become more troubled.
\end{abstract}

* Gatton Endowed Chair in International Banking and Financial Economics, University of Kentucky; and Senior Vice President, Supervision and Regulation Department, Federal Reserve Bank of Boston. This paper was prepared for the National Bureau of Economic Research Strategic Alliances Conference. We would like to thank participants in the pre-conference meeting for their comments on an earlier draft of the paper and Steven Fay for invaluable research assistance. The views expressed are those of the authors, and do not necessarily reflect official positions of the Federal Reserve Bank of Boston or the Federal Reserve System. 


\section{Corporate Affiliations and the (Mis)Allocation of Credit}

The severe economic crisis in Japan, associated with the collapse of the Japanese stock and real estate markets and the dramatic deterioration in the health of the Japanese banking sector, represents one of the major economic events of the late twentieth century. It is even more striking because the second largest economy in the world remained stagnant for more than a decade, and even today shows no evidence of returning to the robust health that characterized most of its postwar history. One potential source of the difficulty in implementing major corporate restructuring has been the web of corporate affiliations that encourages lenders and affiliated companies to support firms that would have otherwise been restructured, sold, or liquidated. We show that a primary driver of lending to troubled firms has been the strength of corporate affiliations, and that lenders not so affiliated are much less inclined to allocate additional credit to deeply troubled firms.

Key contributors to the pattern of Japanese lenders supporting troubled firms are two forms of corporate affiliations that have distinguished Japanese bank-firm relationships. The first, the keiretsu, is characterized by firms having substantial cross-shareholding and extensive explicit and implicit business ties. The second is the main bank system, whereby a firm has a strong relationship with its primary bank, the main bank, with the main bank having extensive shareholdings in the client firm, serving as a major source of short- and long-term financing, and, in many instances, having a representative on the firm's board of directors.

Previous work has documented the importance of Japanese corporate affiliations. Many of these studies highlight the potential beneficial effects of these corporate affiliations, including the ability to reduce agency costs, maintain greater bank debt, and avoid restructuring through costly bankruptcy proceedings. A less benign view of these corporate affiliations is that they 
subvert corporate governance, insulating firms from the discipline that otherwise would come from outside directors, shareholders, and creditors, resulting in suboptimal business and financial decisions. While previous studies have examined how these corporate affiliations affect investment decisions, stock returns, and corporate governance decisions by comparing affiliated and nonaffiliated firms, they have not directly examined how affiliations impact the allocation of credit.

This study utilizes a unique database that enables us to examine the patterns of firm borrowing from banks and nonbank financial firms to determine the extent to which such lending is affected by corporate affiliations, such as the main bank and keiretsu relationships. Any influence of such corporate affiliations on the allocation of credit should be particularly apparent during times of economic stress, such as has been the case in Japan with the continuing banking crisis and the inability of the macroeconomy to recover from the adverse shocks at the beginning of the 1990s.

While strong corporate affiliations encouraged economic growth during the boom times, for example by making credit more available and investment less sensitive to internal cash flows, these same affiliations may inhibit an economic recovery when the economy is in need of major restructuring. Firms with a tradition of protecting employees and maintaining relationships with affiliated companies clearly benefit from a lender willing to provide more flexibility and support than would be the case in a more market-driven credit allocation process. Bank regulation and supervision policies in Japan provide banks with significant nonperforming loans and impaired capital little incentive to be strict with troubled borrowers. In fact, it is in the self-interest of banks to follow a policy of forbearance with their problem borrowers in order to avoid pressure on the banks to increase their own loan loss reserves, further impairing their capital. This leads to 
a policy of banks "evergreening" loans, whereby banks extend additional loans to a troubled firm to enable the firm to make interest payments on outstanding loans and avoid or delay bankruptcy. By keeping the loan current, the bank's balance sheet looks better, since the bank is not required to report such problem loans among its nonperforming loans. Finally, the government, faced with a growing budget deficit and a voting public weary of funding bank bailouts, may prefer banks to continue their policies of forbearance in order to avoid the alternative scenario of massive firm, and perhaps bank, failures and, in particular, the associated costs, both financial and political.

The primary objective of this study is to investigate the impact of main bank and keiretsu affiliations on credit allocation during periods of firm and/or bank distress to determine the extent to which credit has been misallocated due to the pressures emanating from such corporate affiliations. We find that corporate affiliations, both from main banks and strong keiretsu ties, increase the likelihood of a firm receiving additional financing as its health deteriorates. Furthermore, this perverse effect does not occur when the lender is a nonbank without keiretsu ties to the firm. We also find evidence of the evergreening of loans and of indirect government support for troubled main banks.

While many Japanese firms have been insulated from market pressures by their strong relationships with affiliated lenders, this is not necessarily good news for the Japanese economy. If scarce credit is allocated to uncompetitive and troubled firms, Japan will not experience the natural cleansing that results from the major restructuring that typically occurs in an economic downturn. This will inhibit the ability of the Japanese economy to recover from the current economic malaise, as well as adversely affecting the longer-run growth potential of the economy. 
The rest of the paper is as follows. The next section provides some background on corporate affiliations and the associated literature that has developed on the potential benefits and costs of such affiliations. The second section discusses the role of corporate affiliations in allocating credit in the Japanese economy. The third section discusses the data and methods The fourth section provides the results. The final section provides our conclusions.

\section{Corporate Affiliations in Japan}

Corporate affiliations have received a great deal of attention in descriptions of the Japanese economy and have played a key role in many explanations of Japanese economic performance, both during the Japanese "miracle" characterized by rapid growth following World War II and during the "lost decade" of the 1990s. Prior to World War II, powerful family corporate groups centered on family controlled banks, called zaibatsus, controlled most major firms. After the war, zaibatsus were broken up. However, to prevent loss of ownership control, Japanese firms began to purchase shares in affiliated financial or industrial firms (Morck and Nakamura 1999; Morck, Nakamura and Shivdasani 2000; Hoshi and Kashyap 2001). These corporate affiliations, cemented with extensive cross-shareholding and interlocking boards of directors, represent direct and indirect business ties termed keiretsus.

A potential benefit of keiretsu affiliations is that management is able to secure long-term financing and business relationships, with the managerial monitoring conducted by firms with an equity stake and information about the firm generated by the extensive business relationships (Jensen 1989). Such relationships can reduce the costs to a firm when it encounters financial difficulties, since financially troubled firms can have difficulty convincing suppliers, customers, and creditors of their viability. Affiliations can reduce the costs of providing information to stakeholders of a firm's true financial condition and improve the ability to renegotiate or provide 
terms that allow the firm to remain viable. Because affiliations allow all affiliated firms to share in the costs as well as the benefits associated with the provision of financial support to an affiliated troubled firm, corporate affiliations can avoid some of the problems with the asymmetric nature of the incidence of the benefits and costs associated with the granting of debt relief by creditors, whereby the benefits, but not the costs, are shared with equity holders, suppliers, and customers (Hoshi, Kashyap and Scharfstein 1990). Thus, affiliations can potentially improve information sharing, reduce the asymmetry in information among stakeholders, and more evenly distribute the benefits and costs of providing additional support to a financially troubled firm. Consistent with there being benefits to affiliation relationships, Hoshi, Kashyap and Scharfstein (1990) find that among firms experiencing financial distress, keiretsu firms invest and sell more than those firms that are not members of a keiretsu group. A second important form of affiliation is provided by the main bank system. The banking relationship in Japan is far more important than in the United States for a number of reasons. First, Japanese firms are more reliant on bank debt than firms in the United States, although bond financing has become increasingly important over the past decade (Hoshi and Kashyap 1999). Second, the main bank typically is a significant equity holder in the firm, and the borrowing firm usually owns shares in its main bank. Third, management and directors of the firm frequently have served in managerial positions at the bank. Fourth, the main bank is expected to take a leading role in restructuring the firm should it experience financial difficulties. Finally, the main bank often provides financing for customers and suppliers of the firm, since many of the firms are often part of the same keiretsu.

The main bank takes primary responsibility for monitoring the firm and can serve as a form of corporate governance (Kaplan and Minton 1994). The main bank is particularly 
important during times of distress, when it can require changes in management and alter the board of directors (Kang and Shivdasani 1995; Morck and Nakamura 1999). This oversight provided by the bank, both a debt and equity holder, can reduce typical information asymmetries, resulting in firms with a main bank having greater access to external credit, which, in turn, affects firms' investment decisions (Hoshi, Kashyap and Scharfstein 1991). However, there is a dark side to this close lending relationship: If the bank rather than the borrower becomes troubled, the ability of the firm to finance investment may be impeded (Gibson 1995; Kang and Stultz 2000; Klein, Peek and Rosengren 2002).

During the 1980s and early 1990s, most studies of Japanese corporate affiliations found significant benefits. These studies emphasized the unique features of Japanese corporate affiliations that reduced agency costs (Hoshi, Kashyap, and Scharfstein 1993; Hoshi, Kashyap, and Scharfstein 1990). Firms with intertwined business relationships, shareholding relationships, board of directors relationships, and financing relationships with other firms should have substantially more information about that firm than do external monitors. Furthermore, to the extent that a firm's main bank or members of its keiretsu would be willing to provide backup financing should the firm become financially troubled, firms were able to maintain a higher ratio of bank debt relative to their total assets. However, the benefits of close firm-main bank ties may be limited. For example, while Weinstein and Yafeh (1998) find that a close relationship with a firm's bank increases the availability of credit, this does not lead to higher profitability or growth for the firm, perhaps because the bank discourages the firm from investing in high risk, high expected return projects, or because the bank extracts all the rents.

More recently, studies have been more critical of Japanese corporate affiliations, viewing such affiliations as a problem that has contributed to a decade of subpar economic growth, rather 
than as an alternative market model (Kang and Stultz 2000; Morck and Nakamura 1999). If the primary role of corporate affiliations is to insulate management from market forces by enabling firms to avoid the discipline that can be provided by external creditors and investors, this limiting of outside corporate governance would manifest itself in a misallocation of credit. Strong corporate affiliations would allow weak firms to sustain their operations relatively unchanged, rather than being forced by external creditors and shareholders to make the tough restructuring choices necessary to recover.

Still another view suggests that the debate about the positive and negative contributions of keiretsu and main bank relationships is misguided, insofar as keiretsus do not even exist and main banks do not play any meaningful role (Miwa and Ramseyer 2001a, 2001b). While Japan cannot be characterized as a bank-centered economy prior to its buildup for World War II, the view that keiretsu and main bank relationships played no role in the postwar Japanese economy is quite suspect (for example, Hoshi and Kashyap 2001; Milhaupt 2001a, 2001b). However, with the recent financial deregulation, the role of keiretsu and main bank relationships is waning, with the emergence of an active bond market, the erosion of cross-shareholding ties, the continued weakening of both firms and banks, and increasing market pressures on both firms and banks. Thus, the Japanese financial structure appears to be moving back in the direction of its prewar environment, when financial markets played a much more important role in corporate governance and in the allocation of equity and credit (for example, Hoshi and Kashyap 2001; Milhaupt 2001b).

II. Corporate Affiliations and Weakened Banks: Implications for Lending Behavior The Japanese main bank system has been a key distinguishing feature of the Japanese financial system. While relationship lending has been found to be important in the United States 
(Petersen and Rajan 1994), banks and borrowers in Japan frequently have interlocking directorates, cross shareholdings, and affiliated companies that make their lending relationships much stronger. With Japanese banks having both equity and debt relationships with their borrowers, and sometimes even sharing personnel, it is generally assumed that a close bank-firm relationship provides the bank with very good information about the financial condition of the firm, significantly reducing monitoring costs and potential agency problems. Similarly, close ties among keiretsu members should also result in informational advantages about other members relative to outside lenders.

Improved information flows are an important advantage of the main bank and keiretsu systems, with the improved information flows to affiliated lenders becoming particularly valuable during periods of economic distress, when asymmetric information problems worsen. At such times, the interests of managers may not be aligned with those of shareholders and debt holders. In particular, managers worried about their jobs may not have a strong incentive to fully disclose the extent of emerging problems at the firm. Furthermore, the persistent slow economic growth and the continuing declines in land prices throughout the 1990s, following the sharp declines in land and stock prices at the beginning the decade, produced an environment characterized by generally increased levels of uncertainty and sometimes rapid changes in the health of individual firms. Under these conditions, corporate affiliations that improve information flows to lenders have the potential to allow affiliated lenders to allocate credit more efficiently.

The combination of the severe problems at many individual firms and the crisis in the banking system during the 1990s produces a natural experiment that can be exploited to distinguish between alternative hypotheses about the role played by main banks and other 
affiliated lenders. As banks came under increasing pressure from binding capital ratios, they faced difficult choices about how best to shrink their balance sheets. One option is for banks to shrink their foreign operations, which will typically affect foreign borrowers with a weaker banking relationship than is typical of long-standing domestic borrowers. Indeed, this seems to be the path initially followed by Japanese banks beginning in the early 1990s (Peek and Rosengren 1997, 2000). The reductions in lending were initially focused on loans to firms in the United States and Europe, followed later by reductions in lending to firms in Southeast Asia. Although the domestic Japanese economy was insulated from declining bank loans initially, by 1995, continued deterioration in real estate prices, and the Japanese economy more generally, resulted in lowered bank ratings, as well as the failure of some banks, and significant increases in the Japan premium (Peek and Rosengren 2001), contributing to increased pressure on Japanese banks to shrink domestic assets to maintain capital-to-asset ratios.

These factors increased the need for Japanese banks to rethink how they were utilizing their scarce capital. Thus, faced with the necessity to shrink domestic lending, capitalconstrained Japanese banks were forced to make choices about which firms would continue to receive scarce loans. How were banks to trade off their responsibilities to finance firms with strong main bank and keiretsu ties, even though many of these firms had poor prospects, with the need to make sound business decisions that would direct credit to the most creditworthy borrowers, even if they were not closely affiliated with the bank? At the same time, banks faced growing pressure from government entities to continue lending to troubled firms in order to avoid a credit crunch and a sharp increase in the unemployment rate and firm bankruptcies.

The primary hypothesis investigated in this study is that main banks and keiretsu relationships contributed to the misallocation of credit during the 1990s, as banks came under 
pressure to improve capital ratios. If main banks exploit superior knowledge about firms that borrow from them derived from their affiliations with those firms, the probability that a main bank increased its exposure to a troubled firm would be low for affiliated firms that experienced particularly poor performance. The bank would use its access to superior information about the highest expected returns among alternative borrowers to allocate its shrinking pool of funds in a way that eliminated marginal credits, so that the bank's loan portfolio would become increasingly weighted toward firms with the best prospects. If, instead, the consequences of affiliations were to protect the entrenched management of the firm, and, by enabling the firm to make interest payments and avoid or delay bankruptcy, mitigate the damage to the bank's reported balance sheet information, the probability that an affiliated troubled firm would receive additional credit from its main bank would be enhanced by poor firm performance, as both the main bank and the firm's management sought to forestall the realization of losses.

Forbearance by bank regulators provided both the opportunity and the incentive for troubled banks to behave in their own self-interest by continuing to provide credit to severely troubled firms based on the severity of the bank's own health and on its current exposure to those firms. In order to prevent further disclosure of problem loans at a troubled bank that would increase its reported nonperforming loans and require the bank to make additional loan loss provisions and loan charge-offs, a bank may continue lending to troubled firms to provide sufficient financing to keep otherwise bankrupt firms afloat. For example, banks might provide funds to firms to enable them to make the interest payments on their outstanding loans from the bank to prevent the bank having to classify the loans as nonperforming. While this "evergreening" of loans benefits the firm, it also improves the bank's reported balance sheet data. To the extent that additional loans allow a firm to avoid bankruptcy, the bank avoids a 
further increase in its reported nonperforming loans (that includes loans to bankrupt firms as well as loans that are not current on interest payments), as well as avoiding a further write down of its capital. However, while such a strategy may improve the appearance of the bank's balance sheet in the short run, in the long run, such a strategy could result in far greater losses to the bank and scarce credit being allocated to firms with the least productive investment opportunities.

Keiretsu ties may also affect main bank lending, although the direction of the effect is ambiguous. To the extent that a main bank in the same keiretsu as the firm feels a stronger obligation to come to the aid of a troubled firm, the bank would increase credit availability to the firm. Alternatively, the main bank might reduce its exposure to the firm while other members of the keiretsu shouldered more of the burden of the bailout. In that case, secondary banks and nonbanks in the same keiretsu as the firm would tend to increase the availability of credit to the firm as the main bank shrank its exposure. Similarly, for secondary lenders not in the same keiretsu as the firm, one might expect the absence of corporate affiliations to allow such lenders to base their lending decisions on the prospects of the borrowing firm, so that their lending would be positively related to firm health. However, to the extent that nonaffiliated lenders are subjected to pressure from either the government or the firm's main bank, as organizer of support for a troubled firm, to participate in the rescue, nonaffiliated lenders may still aid such firms, although any correlation between increased lending and deteriorating firm health would be weaker than for affiliated lenders. In that case, one might expect to find that the behavior of nonaffiliated lenders would be sensitive to the degree of exposure of the firm's main bank and to the main bank's health. 
III. Data and Methods

We use a rich new panel data set to examine bank lending patterns in order to determine how Japanese banks reacted to the economic problems in the 1990s, and how these reactions affected credit availability to Japanese firms. By using Japanese firm-level data, we are able to link individual Japanese firms to their individual lenders. By identifying the main bank and keiretsu relationships, differences in the magnitudes of changes in a firm's borrowing from different categories of lenders, particularly as firms become more troubled and the financial health of lenders deteriorates, can be used to better understand the effects of corporate affiliations on the allocation of credit to affiliated and nonaffiliated firms. This linking of individual lenders to individual borrowers is critical for understanding how lending disruptions created by problems at financial institutions can be transmitted to the real economy. Such a link cannot be made clearly in many other countries, such as the United States, where bank-borrower relationships are considered private information.

For our tests that focus on the patterns of lending by main banks, secondary banks, and nonbank lenders, we use annual data for a sample period from 1995 through 1999 . We focus on this period because it is the period when banks were seriously capital constrained. To test whether credit is allocated based in part on the strength of corporate ties, we examine the pattern of loans obtained by all firms included in the Pacific-Basin Capital Market Databases (PACAP), which includes all first- and second-section firms that are traded on the Tokyo stock exchange. The PACAP database includes the balance sheet and income statements of firms based on their fiscal year-end reports. We identify each firm's main bank as the first listed reference bank in the Japan Company Handbook. The identification of keiretsu membership and the share of ownership by keiretsu firms among the top 10 equity holders of keiretsu firms are obtained from 
Industrial Groupings in Japan: The Anatomy of the Keiretsu by Dodwell Marketing Consultants. Bank capital and nonperforming loan data are obtained from Bankscope, produced by FitchIBCA. The data for loans outstanding to firms by each lender is obtained from the Nikkei Needs database, with loan reporting based on the firm's fiscal year. To avoid timing problems, we limit our sample to those firms with a fiscal year that ends in March, which is by far the date most commonly used by Japanese firms, as well as corresponding to the March balance sheet and income reports by banks.

We first estimate the probability that a bank increases credit to a firm, controlling for firm and bank characteristics. By allowing for differential effects for main banks and for keiretsu relationships, we can deduce whether troubled banks increase lending based on the strength of corporate ties between the bank and the firm rather than basing the decision primarily on superior information about the investment prospects of affiliated firms. By distinguishing between the lending behavior of affiliated lenders and unaffiliated lenders, we can deduce whether keiretsu and/or main bank ties affect credit availability, and whether any differences are sensitive to the health of the firm or the health of the bank.

We investigate the contribution of main bank and keiretsu affiliations in determining the allocation of credit to firms by capital-constrained banks by estimating the following logit equation:

$$
\begin{gathered}
\operatorname{Pr}\left(\text { LOAN }_{\mathrm{i}, \mathrm{j}, \mathrm{t}}\right)=\mathrm{a}_{0}+\mathrm{a}_{1} \text { AFFIL }_{\mathrm{i}, \mathrm{j}, \mathrm{t}-1}+\mathrm{a}_{2} \text { FIRM }_{\mathrm{i}, \mathrm{j}, \mathrm{t}-1}+\mathrm{a}_{3} \text { BANK }_{\mathrm{i}, \mathrm{j}, \mathrm{t}-1}+\mathrm{a}_{4} \text { MB }^{*} \operatorname{HEALTH}_{\mathrm{i}, \mathrm{j}, \mathrm{t}-1}+ \\
\mathrm{a}_{5} \text { SK}^{*} \text { HEALTH }_{\mathrm{i}, \mathrm{j}, \mathrm{t}-1}+\mathrm{a}_{6} \text { TIME }_{\mathrm{i}, \mathrm{j}, \mathrm{t}}+\mathrm{u}_{\mathrm{i}, \mathrm{j}, \mathrm{t}}
\end{gathered}
$$


The dependent variable has a value of one if loans to firm $\mathrm{j}$ by bank $\mathrm{i}$ increased from year $\mathrm{t}-1$ to year $t$, and zero if the bank's loans to firm $j$ were unchanged or decreased from year $t-1$ to year $t$. We focus on increases in loans, since that requires the lender to take action. A decline in loans outstanding to a firm could result passively from an outstanding loan maturing, as well as from a lender calling a loan or refusing to renew a loan. For a given firm, the regression sample will contain in each year one observation for each bank from which the firm borrows in that year.

AFFIL is a vector of variables reflecting group affiliations. These variables include a set of $(0,1)$ dummy variables, as well as a set of continuous variables. KEIR is a dummy variable that has a value of one if the firm is in one of the eight bank-centered financial (horizontal) keiretsus (Mitsubishi, Mitsui, Sumitomo, Fuyo, Dai-Ichi Kangyo, Sanwa, IBJ and Sakura), and zero otherwise. In some specifications, we also distinguish among three subsets of keiretsus: the three related to the major pre-war ziabatsus (Mitsubishi, Mitsui and Sumitomo); the other three keiretsus related to zaibatsus (Fuyo, Dai-Ichi Kangyo and Sanwa); and the two keiretsus not related to zaibatsus (IBJ and Sakura). This allows for differing strengths of keiretsu relationships. PK is the percent ownership of the firm by keiretsu members among the top ten equity holders. The next three variables are associated with the main bank ties of the firms, reflecting the strength of the tie and the health of the main bank. MBLMB is measured as main bank loans to the firm as a percentage of the main bank's total loans to all firms. MBLFD is measured as main bank loans to the firm as a percentage of the firm's total debt. MBPCPR is the percent change in the stock value of the firm's main bank over the prior year.

FIRM is a vector of variables intended to capture firm health and other characteristics of the firm, including controlling for loan demand. The variables include the firm's return on assets (FROA) during the prior year, the percent change in the firm's equity price over the prior year 
(FPCPR), the firm's liquid assets as a percentage of its total assets (FLIQA) for the prior year, and the percent change in the firm's sales (FSALES) over the prior year. We also control for other firm characteristics by including the logarithm of the firm's total real assets (FLASSET), a set of $(0,1)$ dummy variables indicating whether a firm just entered the bond market (FENBMKT), is in the bond market (FINBMKT), or just left the bond market (FEXBMKT), and a set of industry dummy variables.

While the estimated coefficients on FROA, FPCPR, FLIQA, and FSALES reflect firm health, these variables also may serve as proxies for the strength of the firm's loan demand. This issue is addressed below. The reported regressions do not include FPCPR, since it was dominated as a measure of firm health by the other measures, never having a significant estimated coefficient. This may not be surprising, since once a Japanese firm's health has deteriorated substantially, its stock price movements are often dominated by news concerning the likelihood that the firm's lenders will rescue (bailout) the firm and the magnitude of any assistance the firm is likely to receive from its lenders.

BANK is a vector of variables intended to capture bank health. These variables include the percent change in the bank's equity price over the past year (BPCPR), the bank's risk-based capital ratio (BRBC), and the bank's nonperforming loans as a percentage of its total assets (BNPLA). The reported regressions focus on BPCPR, which dominated the other two measures. This is not surprising, given the widely held views that bank capital ratios in Japan are substantially overstated and that the nonperforming loan ratios substantially understate the severity of the deterioration in the quality of loans in bank portfolios. To the extent that analysts are able to penetrate the veil of reported capital and nonperforming loan ratios, stock prices should reflect the best estimates of bank health. 
In order to isolate the differential effects of corporate affiliations, we include two sets of interaction terms, one for main bank ties (MB*HEALTH) and one for keiretsu ties (SK*HEALTH). The interactive variables for the main bank ties are interacted with a $(0,1)$ dummy variable that has a value of one if the bank is the firm's main bank (MBANK). The differential effects of keiretsu ties are obtained by using a $(0,1)$ dummy variable that has a value of one if the lender is in the same keiretsu as the firm (KSAME). The variables in the set of interaction terms include those in the base specification that are intended to measure firm or bank health, as well as the extent of the main bank's exposure to the firm. The set of main bank interaction variables include MBANK, in addition to MBANK interacted with each of the following measures of firm health, bank health, and main bank ties: KSAME, FROA, FLIQA, FSALES, BPCPR, MBLMB, and MBLFD. The set of keiretsu interaction variables includes KSAME, in addition to KSAME interacted with the following variables: FROA, FLIQA, FSALES, BPCPR, MBPCPR, MBLMB, and MBLFD. Note that we did not include both BPCPR and MBPCPR in the set of main bank interaction variables, since once they are multiplied by MBANK, the two interactive variables are identical.

We include a set of annual time dummy variables to capture the effects of the macroeconomy. We use this specification rather than using a set of continuous macroeconomic variables because most Japanese macroeconomic variables are known to have significant measurement issues. These annual dummy variables will capture the average effect of economic conditions in each year.

While the annual time dummy variables and the set of industry dummy variables control for loan demand at the aggregate level, the set of dummy variables for a firm entering, exiting, or being in the bond market should help control for shifts in loan demand should help control for 
loan demand at the individual firm level. However, as mentioned above, the measures of firm health included in the equation are likely to be correlated with the firm's need for external financing. By focusing only on the differential effects associated with the behavior of the firm's main bank and those lenders in the same keiretsu as the firm compared to the effects associated with unaffiliated lenders, we hope to avoid the difficulty of controlling for shifts in loan demand at the firm level. Insofar as a change in a firm's condition that affected its general loan demand is captured by the base regression, we should be able to avoid shifts in loan demand contaminating the measurement of the differential effects associated with affiliated lending.

For the first specification, only firm-lender observations for lenders that are markettraded banks are included in order to be able to control for bank health. The base group of lenders will be secondary banks that are not members of the same keiretsu as the firm. This would include all observations of firms that are not members of a keiretsu, as well as all observations of loans to a firm by lenders that are either in a different keiretsu or not members of a keiretsu. The estimated coefficients on the interactive terms are then interpreted as measures of the extent to which lending by main banks or by banks in the same keiretsu as the firm responds differently to measures of firm health, bank health, and the strength of main bank ties. Does affiliated lending decline with firm health or is the effect perverse, suggesting that corporate affiliations tend to protect the entrenched management of troubled firms? Similarly, is lending inversely related to bank health, suggesting that banks may be lending to weakened firms in order to protect their own balance sheets from a further increase in reported nonperforming loans that might require them to make additional provisions for their problem loans?

The second major specification enlarges the set of lenders to include not only markettraded banks, but also nonbank lenders and government-controlled lenders. Again, the focus will 
be on the differences in the estimated coefficients on firm health, main bank health, and the strength of main bank ties across the various categories of lenders. The underlying hypothesis is that the various groups of lenders will have different motivations that determine how they allocate credit to firms.

\section{Empirical Results}

As a preliminary to the estimation results, Table 1 presents information on the extent to which our sample of firms relies on bonds and loans to finance their operations. The numbers in the table are based on values for each category calculated as a percentage of firm assets for both the beginning of our sample, 1995, and the end of the sample, 1999, and separately for firms that are and are not members of a keiretsu. The table contains the mean values for those percentages over the relevant set of firms. One of the more striking results in the table is that during this time of severe problems in the banking sector, firms decreased their reliance on bonds, with the percentage decline for non-keiretsu firms (34) being about double that for keiretsu firms (16.5). At the same time, both keiretsu and non-keiretsu firms increased their reliance on loans. Keiretsu firms, which rely more heavily on loans than do non-keiretsu firms, obtained most of the increase in loans from members of their keiretsu ( 97 of the 115 basis point increase in the share), from banks (109 basis points), and, in particular, from their main bank (99 basis points). Although keiretsu firms rely much more heavily on nonbanks than do non-keiretsu firms, that share increased only slightly during the period. Perhaps surprisingly, keiretsu firms rely much more heavily than do non-keiretsu firms on government-controlled banks, although that share did not increase during the period. For non-keiretsu firms, loans increased as a share of assets by one full percentage point (100 basis points). Bank loans accounted for a 116 basis point increase, yet less than half of the increase came from the main banks. Reliance on both 
nonbanks and government-controlled banks declined. Thus, the primary differences between keiretsu and non-keiretsu firms over the 1995 to 1999 period are the sharper decline in reliance on bonds by non-keiretsu firms and the pattern whereby the increase in loans for keiretsu firms was accounted for primarily by main banks. While secondary banks accounted for about half the increase in loans to non-keiretsu firms, their reliance on nonbanks fell, while keiretsu firms increased their reliance on nonbanks.

Table 2 contains the means, standard deviations, minimum values, and maximum values for the explanatory variables in the base regression for the set of observations for loans from market-traded banks. Those variables, both individually and interacted with the main bank and same keiretsu dummy variables, are used to obtain the results from estimating the logit specification shown in equation 1 that are shown in Table 3. Because including aggregate regressors such as the set of annual dummy variables in the equation suggests a likely correlation among regression errors within a particular year, we compute robust coefficient standard errors that allow for dependence of regression errors within years. As discussed above, the dependent variable is a $(0,1)$ dummy variable having a value of one if the bank increased lending to the firm, and zero otherwise.

The estimates in the first column of Table 3 are based on the panel of firm-lender observations that includes all first- and second-section firms on the Tokyo stock exchange and market-traded banks for which all required data are available. Later specifications are expanded to include nonbank and government-controlled lenders, as well as market-traded banks. The second column contains the results for the same specification as column 1, but with the observations with extreme values excluded from the sample. Outlier observations are defined as 
those for which any one of the regressors has a value that is more than four standard deviations from its mean value. The removal of outliers reduces the sample by about 4 percent.

The table contains three sets of estimated coefficients. The first nine are for the base group of lenders, banks that are neither the firm's main bank nor in the same keiretsu as the firm. The second set of eight estimated coefficients, each associated with a variable name that begins with $\mathrm{MB}$, captures the differential response of main banks, measured relative to that of the base group. The final set of eight coefficients, each associated with a variable name that begins with $\mathrm{S}$, captures the differential response of banks in the same keiretsu as the firm, measured relative to that of the base group.

The first two explanatory variables capture the effect of the keiretsu affiliation on the probability that banks extend additional credit to firms. KEIR, which has a value of one if the firm is a member of a keiretsu, has an estimated coefficient that is positive, but insignificant. The estimated coefficient on PK, the percent ownership of the firm by keiretsu members among the firm's top ten equity holders, is negative and statistically significant, indicating that the more closely the firm is tied to its keiretsu affiliates through equity ownership, the less likely are banks to increase loans to the firm. This result might reflect keiretsu firms relying more heavily on members of its keiretsu, especially nonbanks, for providing financing during difficult times.

The next three explanatory variables capture the effect of main bank relationships on the probability that secondary banks not in the same keiretsu (the base group) provide additional loans to the firm. The estimated coefficient for MBLMB, loans to the firm by its main bank as a percentage of total loans by the bank to all firms, is positive, but statistically insignificant. MBLFD, main bank loans to the firm as a percentage of the firm's total debt, has an estimated coefficient that is positive and significant. This suggests that nonaffiliated secondary banks are 
more likely to extend additional loans to a firm the more the firm relies on its main bank for credit. MBPCPR, the percentage change in the stock value of the firm's main bank over the prior year, has an estimated coefficient that is negative, but not significant.

The next three variables capture the impact of the financial condition of the firm on the probability that nonaffiliated secondary banks will extend additional credit to the firm. The estimated coefficient on the firm's return on assets is negative and significant, indicating that the lower the firm's return on assets, the more likely that these banks will provide additional financing. The estimated coefficient on the firm's liquid assets as a percentage of its total assets is negative and significant, indicating that the worse is the firm's liquidity, the more likely that these banks will provide additional financing. The estimated coefficient on firm sales growth is positive and significant, indicating that the stronger is a firm's sales growth, the greater is the probability that nonaffiliated secondary banks will provide additional financing.

Each of these three effects is likely to reflect, at least in part, the strength of the firm's loan demand. Of particular interest for this study is which category of lenders, if any, satisfy the surge in distress borrowing as a firm's low return on assets weakens its capital position and as its deteriorating liquidity position pushes the firm closer to failure should it be unable to secure additional funding. While the differential effects to be discussed below are the key to answering this question, the estimates for the base group indicate that even nonaffiliated secondary banks provide some additional credit as a firm's health weakens. Perhaps this is a response to government pressures to keep troubled firms alive or to pressures from the firm's main bank, as it orchestrates the bailout of a severely troubled firm, for each lender to provide its proportional share of any funds advanced to the firm. 
$\mathrm{BPCPR}$, the percentage change in the stock value of the bank over the prior year, is intended to capture the effect of the lender's health on the probability that it is willing to provide additional credit to the firm. While its estimated coefficient is positive, it is not significant. Thus, for nonaffiliated secondary banks, there is no evidence that weaker banks tend to evergreen loans in order to protect their own balance sheets.

The next set of variables captures the extent to which main banks react differently than nonaffiliated secondary banks in providing additional credit to firms. The estimated coefficient on MBANK is positive and significant, indicating that main banks are more likely than nonaffiliated secondary banks to provide additional credit to firms, other things equal. However, if the main bank is in the same keiretsu as the firm, that is, MB*KSAME has a value of one, the bank is less likely than main banks not in the same keiretsu (but still more likely than nonaffiliated secondary banks) to provide additional credit to the firm, since the estimated coefficient is negative and significant (although smaller in absolute value than that on MBANK), perhaps because the firm has a network of other keiretsu members from which it is able to obtain any required additional credit. The estimated coefficients on both MB*FROA and MB*FLIQA are negative and significant, indicating that main banks are more likely to extend additional credit as a firm's health deteriorates compared to the base group of lenders. This is consistent with main banks feeling a stronger obligation to come to the aid of its troubled firms than is the case for nonaffiliated secondary lenders. However, MB*FSALES does not have a significant estimated coefficient, indicating no evidence of main banks reacting differently than nonaffiliated secondary banks to a firm's sales growth rate.

The estimated coefficients on the next three variables indicate that the likelihood of the main bank providing additional credit, relative to nonaffiliated secondary banks, is affected by 
the strength of the banking relationship and the financial condition of the main bank. The estimated coefficient on MB*MBCPR is negative and statistically significant, indicating that if the main bank's stock price has performed poorly, the main bank is more likely to extend additional credit to the firm. The estimated coefficient on MB*MBLMB is positive and significant, indicating that main banks are more likely than nonaffiliated secondary banks to provide additional credit to firms the greater its exposure to the firm. Similarly, MB*MBLFD has an estimated coefficient that is positive and significant, indicating that the higher the main bank's share of the firm's total debt, the greater the likelihood that the main bank will extend additional credit to the firm. All three of these effects are consistent with the main bank evergreening loans to troubled borrowers in order to protect its own balance sheet.

Among the interactive variables intended to distinguish the behavior of banks in the same keiretsu as the firm from nonaffiliated secondary banks, only two estimated coefficients are statistically significant. The dummy variable for the firm and the bank being in the same keiretsu has an estimated coefficient that is positive and significant, indicating that banks in the same keiretsu as the firm are more likely to extend additional credit to a firm relative to nonaffiliated secondary banks. This effect is roughly the same magnitude as the net effect for a main bank in the same keiretsu $(.843-.271=.572)$. The negative estimated coefficient on SK*BPCPR indicates that banks in the same keiretsu as the firm, compared to nonaffiliated secondary banks, are more likely to extend additional credit to the firm the weaker has been the bank's stock price performance over the previous year, suggesting that banks in the same keiretsu may practice the evergreening of loans to affiliate firms.

The estimates in the second column of the table indicate that the results are robust to removing outlier observations. Of the 14 estimated coefficients in column 1 that are statistically 
significant, only two, FSALES and SK*BPCPR, lose their significance when observations with extreme values for the regressors are removed. On the other hand, one additional variable, MB*FSALES, now has an estimated coefficient that is statistically significant, indicating that stronger firm sales growth reduces the probability, relative to nonaffiliated secondary banks, that the firm's main bank will increase loans to the firm. Thus, with the outlier observations removed, each of the interactive variables highlighting the differences between main banks and nonaffiliated secondary banks has a statistically significant effect.

Although not shown in the table in order to conserve space, each regression includes a measure of firm size, a set of three bond market variables, a set of annual dummy variables, and a set of industry dummy variables, as described above. The logarithm of the firm's real assets always has a negative and significant estimated coefficient here and in later specifications. Among the bond market variables, the dummy variable that has a value of one when a firm enters the bond market has a negative coefficient, as would be expected, that is significant at the 10 percent level. The dummy variable that has a value of one when a firm exits the bond market has a positive estimated coefficient, as would be expected, that is always significant at the 1 percent level, both here and in later specifications. Including a separate dummy variable for each time period should control for the average state of the economy in each period. The set of industry dummy variables should control for any systematic differences in loan demand across industries.

The results in Table 3 imply that as a firm's health deteriorates, secondary banks not in the same keiretsu as the firm tend to increase lending to the firm, and main banks are even more likely than nonaffiliated secondary banks to increase lending to troubled firms. This perverse result may be due to several factors. First, Japanese banks may be responding to significant 
government pressure to avoid a credit crunch or a precipitous decline in economic conditions that might occur if they were to reduce credit to troubled firms. In fact, the Shinsei bank, which was acquired by foreign investors, has taken the unusual step of complaining publicly about government pressure to support troubled credits. This pressure has reportedly been to provide additional financing to non-keiretsu as well as keiretsu members, consistent with our results that even nonaffiliated banks tend to increase credit to troubled firms.

A second possibility is that Japanese banks, which are well known for their practice of evergreening loans, may be providing additional loans to troubled borrowers in order to allow the firms to make interest payments to keep the loans current. Banks under pressure to maintain capital ratios have an incentive to minimize reported problem loans, those not current or made to firms that have declared bankruptcy, so that they do not have to make additional loan loss provisions, which would reduce a bank's earnings, and thus capital. Such practices, particularly during a time of reduced bank lending, would appear as increases in loans to the most troubled firms.

The second major finding is that the likelihood of a firm obtaining additional credit from its main bank does differ significantly from that of obtaining additional credit from its nonaffiliated secondary banks, although that difference is smaller if the main bank is in the same keiretsu as the firm. While heavy reliance by a firm on its main bank for credit increases the probability of nonaffiliated secondary banks increasing loans to the firm, presumably because it signals main bank support for the firm, main banks are even more responsive to firms that are heavily dependent on them for credit. In addition, main banks are more likely to increase loans to firms to which they have a significant exposure relative to their own total loans outstanding. Furthermore, this main bank support becomes stronger as the main bank's health deteriorates. 
This evidence reinforces the view that banks practice the evergreening of loans, since the incentive to do so rises with increased exposure to the firm and declines in the bank's health.

The third major result is that a bank in the same keiretsu as the firm is more likely to increase lending to the firm compared to a nonaffiliated bank, and the difference is roughly the same whether the bank in the same keiretsu is the firm's main bank or a secondary bank. Furthermore, the stronger are the ownership ties of other keiretsu members to the firm, the less likely it is that banks will increase lending to the firm. A possible explanation for these results is that keiretsu members have access to alternative financing through affiliated suppliers, customers, and nonbank lenders, such as life insurance companies, and, to the extent that the firm needs to expand its debt, may be able to do so through such alternative sources, with the ability of the firm to access this alternative source of funding being positively related to the ownership stake that these affiliated firms have in the firm. This hypothesis is examined more directly in Table 5.

In Table 3, most of the estimated coefficients on the set of same-keiretsu interactive variables were not statistically significant, indicating that the data could not distinguish between the responses of banks in the same keiretsu as the firm and those of nonaffiliated secondary banks to measures of firm health, bank health, and main bank exposure to the firm. However, that specification constrained the coefficients on the same-keiretsu variables to be the same across all eight keiretsus, although several previous studies have found differences across types of keiretsus. Table 4 contains the results of re-estimating the Table 3 specification, with outlier observations removed, allowing the same-keiretsu variables to take on different coefficients across three groupings: keiretsus that are based on the three major prewar zaibatsus (Mitsubishi, Mitsui and Sumitomo); keiretsus based on the three minor zaibatsus (Fuyo, Dai-Ichi Kangyo and 
Sanwa); and the two keiretsus (IBJ and Sakura) that are not based on a prewar zaibatsu. To keep Table 4 concise, we report only the estimated coefficients for each of the same-keiretsu interactive variables. Also, recall that the equation is specified so that the estimated coefficients reflect differences from the base group of lenders, nonaffiliated secondary banks.

The intercept terms, individual dummy variables that have a value of one if the firm is a member of a keiretsu of that type, show that there are differences, on average, across keiretsu types. The estimated coefficient for the major zaibatsu is positive but not significant, for the minor zaibatsu, positive and significant, and for the non-zaibatsu type keiretsu is negative, but not significant. All three of the estimated coefficients for the bank and the firm being in the same keiretsu are positive and significant, with the magnitudes differing somewhat across keiretsu types.

One of the most striking differences in the estimated coefficients across the keiretsu types is for the firm's return on assets. The estimated coefficient on FROA is negative and significant for the major zaibatsu type, negative but not significant for the minor zaibatsu type, and positive and significant for the non-zaibatsu type of keiretsus. This suggests that the extent to which troubled firms receive support from their keiretsu members is influenced by the type of keiretsu. Assuming that the keiretsu ties are strongest for the major zaibatsu type and weakest for the nonzaibatsu type, the pattern of estimated coefficients suggests that the stronger are keiretsu ties, the more likely it is that troubled firms will be supported by their keiretsu banks. In fact, if the firm and bank are in the same non-zaibatsu type, the bank is less likely to provide financing as the financial condition of the firm deteriorates. The negative and significant estimated coefficient on the firm's sales growth for the major zaibatsu type of keiretsu lends further support to this hypothesis, since one would expect that increased sales would result in both greater loan demand 
and a healthier firm. Instead, slower sales growth actually increases the financing by samekeiretsu banks to firms in keiretsus based on major prewar zaibatsus. The estimated coefficient for the minor zaibatsu type is also negative, but is not statistically significant. In contrast, when the keiretsu is not based on a prewar zaibatsu, the estimated coefficient is positive, although not significant.

The estimated coefficients on BPCPR also exhibit differences across keiretsu types. For the major zaibatsu type, the estimated effect is negative and significant at the 10 percent level, indicating that as a bank's health deteriorates, it is more likely to increase lending to firms in the same keiretsu. On the other hand, the effect is positive and significant for banks in the same keiretsu that is based on one of the minor zaibatsus. The estimated coefficient on the main bank being in the same keiretsu is negative for all keiretsu types, and exhibits a pattern of weaker support for the firm the weaker the keiretsu ties. However, only the estimated coefficient for the non-zaibatsu type is significant.

The estimated coefficients on MBPCPR, the change in the stock price of the firm's main bank in the previous year, differ by keiretsu type. The estimated coefficient is positive and significant for the major zaibatsu type, but negative and significant for the minor zaibatsu type of keiretsu. Thus, a financially strong main bank is more likely to result in banks increasing lending to the firm if the firm and the main bank are in the same major zaibatsu type of keiretsu, but less likely to increase lending if they are in the same minor zaibatsu type. Finally, if main bank loans to the firm are a large percentage of the total loans made by the main bank, a bank is more likely to increase lending to the firm if the firm and the bank are in the same non-zaibatsu type keiretsu. Although not significant, the estimated effect has the opposite sign for the major zaibatsu type of keiretsu. 
The Table 4 results confirm that stronger keiretsu affiliations have served to support the weakest firms. The strongest affiliations are likely to be for firms and banks in the same major zaibatsu type of keiretsu. Particularly in these cases, firms with a lower return on assets and slower sales growth are more likely to receive additional loans from banks the stronger are the keiretsu ties. And, other things equal, main banks in the same keiretsu are less likely to provide additional financing to firms the weaker are the keiretsu ties.

Table 5 contains results that are based on an expanded sample of lenders that includes nonbank financial firms, such as insurance companies, and government-controlled banks, as well as the market-traded banks that formed the sample for the previous tables. As with the sample of bank lenders, we differentiate between nonbank financial firms that are and are not in the same keiretsu as the firm. Again, we re-estimate the Table 3 specification, omitting outlier observations, with the estimated coefficients reflecting the differences in responses for each type of lender measured relative to the same base group, secondary banks not in the same keiretsu as the firm (shown in column 1). This distinction is important, since it provides insights into how other keiretsu members might support troubled firms, how government-controlled banks support troubled firms, and whether nonbanks not in the same keiretsu as the firm differ in the degree to which they support troubled firms.

The first column contains the estimated coefficients for our base group of nonaffiliated secondary banks. The estimated coefficients on FROA and FLIQA indicate that even these nonaffiliated banks are more likely to increase lending to firms the weaker are the firms. This may reflect governmental pressure on banks to support troubled borrowers to prevent a credit crunch and an even sharper rise in firm bankruptcies. The only other variable with a significant estimated coefficient is MBLFD, indicating that these secondary banks are more likely to 
increase lending to firms the more the firm's reliance on its main bank. Perhaps they feel that such loans are less risky, insofar as the main bank is more likely to bailout the firm, and thus other lenders, if the firm's health deteriorates substantially.

The second column contains the estimated coefficients for secondary banks in the same keiretsu as the firm. These estimated coefficients represent differential effects relative to those of the nonaffiliated secondary banks, indicating the additional effect emanating from a secondary bank having a keiretsu tie to the firm. Only two estimated coefficients indicate effects that differ significantly from those of nonaffiliated secondary banks. Other things equal, secondary banks in the same keiretsu are more likely to increase credit to the firm. Furthermore, as the firm's health deteriorates, as shown by its return on assets, the more likely that the affiliated secondary bank will increase lending relative to nonaffiliated secondary banks. Thus, keiretsu relationships appear to be valuable to a firm in terms of increasing credit availability as the firm's health deteriorates.

The third column contains the estimated coefficients for main banks not in the same keiretsu as the firm. These estimated coefficients represent differential effects relative to those of the nonaffiliated secondary banks, indicating the additional effect emanating from a main bank relationship with the firm. Six of the seven estimated coefficients are significant. Other things equal, main banks not in the same keiretsu are more likely than secondary banks not in the same keiretsu to increase loans to a firm. In addition, as a firm's health deteriorates, as measured both by a declining return on assets and a decline in liquidity, its main bank is more likely to increase loans to the firm relative to a nonaffiliated secondary bank. These estimates strongly suggest that main bank ties are an important source of support as firms weaken. The significant estimated coefficients on main bank health and main bank exposure indicate that main banks also 
may be behaving in their own self-interest by evergreening loans. The weaker is the main bank's health and the more its exposure to the firm, both relative to all of its outstanding loans and relative to its share of the total debt of the firm, the more likely it is to increase loans to the firm.

The fourth column contains the estimated coefficients for main banks in the same keiretsu as the firm. These estimated coefficients represent differential effects relative to those of the nonaffiliated secondary banks, indicating the additional effect emanating from the combination of a main bank relationship and a keiretsu relationship with the firm. None of the seven estimated coefficients is significant. This indicates that the behavior of a main bank in the same keiretsu as the firm does not differ significantly from that of the base group, nonaffiliated secondary lenders. However, based on the results in column 3, these estimates suggest that there is something about a main bank being in the same keiretsu as the firm that reduces its incentive to support a troubled firm relative to a main bank not in the same keiretsu. Perhaps it is that the burden of supporting a troubled firm can be spread across the other keiretsu members, rather than the firm having to rely primarily on its main bank for support.

The fifth column contains the estimated coefficients for nonbanks not in the same keiretsu as the firm. These estimated coefficients represent differential effects relative to those of the nonaffiliated secondary banks, indicating the extent to which nonbanks may apply different criteria in deciding to supply additional credit to firms. Five of the seven estimated coefficients are significant. Other things equal, as firm's health deteriorates, as measured either by its return on assets or by its liquidity, nonbanks not in the same keiretsu are less likely than secondary banks not in the same keiretsu to increase loans to the firm. Thus, nonaffiliated nonbanks are much less likely to support a troubled firm compared to banks, main or secondary, affiliated or nonaffiliated. On the other hand, nonaffiliated nonbanks are less likely to increase 
lending to firms with stronger rates of sales growth. Finally, these nonbank lenders respond differently to the two measures of the main bank's exposure to the firm. A larger share of the main bank's total loans going to the firm will increase the nonbank's likelihood of increasing loans to the firm, relative to that of nonaffiliated secondary banks, while a larger share of main bank loans to the total debt of the firm will decrease the likelihood of the nonbank increasing loans to the firm.

The sixth column contains the estimated coefficients for nonbanks in the same keiretsu as the firm. These estimated coefficients represent differential effects relative to those of the nonaffiliated secondary banks, indicating any differences in the responses emanating from the combination of being a nonbank and having a keiretsu tie to the firm. Three of the seven estimated coefficients indicate effects that differ significantly from those of nonaffiliated secondary banks. Affiliated nonbanks are more likely to increase loans to firms with stronger sales growth rates relative to nonaffiliated secondary lenders. They also are more likely to increase lending the weaker the health of the firm's main bank, suggesting that their keiretsu ties tend to induce them to help the firm when the main bank becomes troubled and is less able to help. On the other hand, the greater the share of the firm's loans that come from its main bank, the less likely that the affiliated nonbank will increase loans.

The seventh column contains the estimated coefficients for government-controlled banks. These estimated coefficients represent differential effects relative to those of the nonaffiliated secondary banks, indicating any differences in the likelihood of governmentcontrolled banks increasing loans to firms. Four of the seven estimated coefficients are significant. Other things equal, government-controlled banks are less likely than secondary banks not in the same keiretsu to increase loans to a firm. However, government-controlled 
banks are more likely to increase loans to the firm the weaker is the health of the firm's main bank. This could be interpreted as indirect support of a troubled main bank. Furthermore, the larger is the main bank's exposure to the firm, as a share of total main bank loans, the more likely are government-controlled banks to increase lending to the firm, consistent with government banks providing support for main banks by supporting borrowers that are important to the bank, as indicated by the extent of the bank's exposure to the borrower. Interestingly, government-controlled banks produce by far the largest estimated coefficient on MBLMB among all types of lenders. On the other hand, the larger the share of main bank loans relative to the total debt of the firm, the less likely that government-controlled banks will increase loans to the firm relative to nonaffiliated secondary banks.

Our final table attempts to better address the hypothesis that affiliated lenders act on their superior information about the prospects of the firms. Our earlier results were based on publicly available measures of firm health. Those estimates addressed the question of whether affiliated lenders responded differently than nonaffiliated lenders to measures of firm health, bank health, and the main bank exposure to the firm. However, the measures of firm health were not forward-looking. The dependent variable is the percent change in the firm's stock price from period $t-1$ to period $t$. The set of explanatory variables include $(0,1)$ dummy variables that have a value of one if the lender category increased loans to the firm during the previous year, that is, from period t -2 to $\mathrm{t}-1$. Note that to the extent that an increase in loans enables the firm to improve its subsequent performance beyond what it otherwise would have been in the absence of additional lending, the test will be biased in favor of finding a positive estimated coefficient. The specifications also include a set of annual time dummy variables and a set of industry 
dummy variables to control for average stock price movements from year to year and differences across industries.

The first column of Table 6 contains the results for total loans. An increase in total loans to the firm is associated with a decline in the firm's stock price of almost 2 percent during the subsequent year, other things equal. Furthermore, the significant negative estimated coefficient indicates that any embedded positive bias embedded in the estimated coefficient associated with a firm's subsequent performance being improved by access to additional credit is overcome. This result suggests that lenders are not picking winners.

The results in column 2 are more to the point with respect to affiliated lenders possibly exploiting access to superior information about affiliated firms to identify those with the best prospects when making decisions to increase loans. This specification focuses on increases in loans by main banks, distinguishing between those with and without keiretsu ties, and the strength of any ties, as distinguished by type of keiretsu. Each of the estimated coefficients is negative, although only that for main banks in the same keiretsu as the firm that is based on the major prewar zaibatsus is statistically significant. These results are consistent with our earlier results, strongly suggesting that main banks were basing their lending on supporting troubled affiliated firms, rather than exploiting superior information in order to direct lending to those firms with the best prospects. Indeed, the strongest support occurs for firms in the three keiretsus based on the major prewar zaibatsus, which likely have the stronger keiretsu ties.

\section{Conclusions}

This study has presented strong evidence that main bank and keiretsu affiliations have affected the allocation of credit in Japan during the second half of the 1990s, when both firms and banks were severely troubled. However, rather than lenders exploiting their superior 
information about affiliated firms to make additional loans to those firms with the best prospects, they were more likely than nonaffiliated lenders to provide additional loans to firms as firm health deteriorated. In addition, the results indicate that banks have practiced the evergreening of loans, particularly to affiliated borrowers. It also appears that Japanese banks may have been responding to government pressure to avoid a credit crunch or a precipitous decline in economic activity by extending credit to troubled firms. By supporting the weakest firms rather than those with the best prospects, these lenders have misallocated credit.

Just as forbearance by bank regulators has allowed the banks to be slow to restructure, bank support for troubled and noncompetitive firms has prevented the needed restructuring of nonfinancial firms. Thus, while the strong corporate affiliations in Japan insulated many severely troubled Japanese firms from market forces and may have prevented a capital crunch, those same relationships nonetheless exacerbated economic problems for the economy by promoting the allocation of an increasing share of bank credit to many of the firms least likely to use it productively. To the extent that corporate affiliations led to credit being allocated to firms with poor prospects, the economic recovery would be hampered. Thus, by insulating troubled (and perhaps insolvent) firms from market forces that would force either a major restructuring or bankruptcy of the firms, the misallocation of credit would severely hinder the economic recovery and prolong the malaise, consistent with the lost decade of the 1990s. Furthermore, such a misallocation of credit, by inhibiting the needed restructuring of the economy, would adversely impact the long-run growth prospects of the Japanese economy. 


\section{REFERENCES}

Gibson, Michael S. 1995. "Can Bank Health Affect Investment? Evidence from Japan.” Journal of Business, 68, July, 281-308.

Hall, Brian J. and David E. Weinstein. 2000. "Main Banks, Creditor Concentration, and the Resolution of Financial Distress in Japan." In Masahiko Aoki and Gary R. Saxonhouse, eds., Finance, Governance, and Competitiveness in Japan. New York: Oxford University Press, 6480 .

Hoshi, Takeo and Anil Kashyap. 1999. "The Japanese Banking Crisis: Where Did It Come From and How Will It End?" in Ben Bernanke and Julio Rotemberg, eds., NBER Macroeconomics Annual 1999. Cambridge: MIT Press.

Hoshi, Takeo and Anil Kashyap. 2001. Corporate Financing and Governance in Japan. Cambridge, MA: The MIT Press.

Hoshi, Takeo, Anil Kashyap and David Scharfstein. 1990. "The Role of Banks in Reducing the Costs of Financial Distress in Japan." Journal of Financial Economics, 27, 67-88.

Hoshi, Takeo, Anil Kashyap and David Scharfstein. 1991. "Corporate Structure, Liquidity, and Investment: Evidence from Japanese Industrial Groups.” Quarterly Journal of Economics, 106, 33-60.

Hoshi, Takeo, Anil Kashyap and David Scharfstein. 1993. “The Choice Between Public and Private Debt: An Analysis of Post-Deregulation Corporate Financing in Japan." Manuscript.

Kang, Jun-Koo and Anil Shivdasani. 1995. "Firm Performance, Corporate Governance, and Top Executive Turnover in Japan." Journal of Financial Economics, 38, 29-58.

Kang, Jun-Koo and Anil Shivdasani. 1997. "Corporate Restructuring During Performance Declines in Japan." Journal of Financial Economics, 46, 29-65.

Kang, Jun-Koo and Rene M. Stultz. 2000. Do Banking Shocks Affect Borrowing Firm Performance? An Analysis of the Japanese Experience." Journal of Business, 73, 1-23.

Kaplan, Steven N. and Bernadette Minton. 1994. "Appointments of Outsiders to Japanese Corporate Boards: Determinants and Implications for Managers.” Journal of Financial Economics, 36, 225-58.

Klein, Michael W., Joe Peek, and Eric S. Rosengren. 2002. "Troubled Banks, Impaired Foreign Direct Investment: The Role of Relative Access to Credit." The American Economic Review, June, forthcoming.

Milhaupt, Curtis J. 2001a. "Creative Norm Destruction: The Evolution of Nonlegal Rules in Japanese Corporate Governance.” University of Pennsylvania Law Review, 149, 2083-2129. 
Milhaupt, Curtis J. 2001b. "On the (Fleeting) Existence of the Main Bank System and Other Japanese Economic Institutions." The Center for Law and Economic Studies, Columbia University, Working Paper No. 194, November.

Miwa, Yoshiro and J. Mark Ramseyer. 2001a. "The Fable of the Keiretsu." The Harvard John M. Olin Center Discussion Paper No. 316, March.

Miwa, Yoshiro and J. Mark Ramseyer. 2001b. “The Myth of the Main Bank: Japan and Comparative Corporate Governance.” The Harvard John M. Olin Center Discussion Paper No. 333, September.

Morck, Randall and Masao Nakamura. 1999. "Banks and Corporate Control in Japan." Journal of Finance, 54, 319-39.

Morck, Randall, Masao Nakamura, and Anil Shivdasani. 2000. "Banks, Ownership Structure and Firm Value in Japan." Journal of Business, 73, 539-67.

Peek, Joe and Eric S. Rosengren. 1997. "The International Transmission of Financial Shocks: The Case of Japan." The American Economic Review, 87, September, 495-505.

Peek, Joe and Eric S. Rosengren. 2000. "Collateral Damage: Effects of the Japanese Bank Crisis on Real Activity in the United States." The American Economic Review, 90, March, 3045 .

Peek, Joe and Eric S. Rosengren. 2001. "Determinants of the Japan Premium: Actions Speak Louder Than Words." Journal of International Economics, 53, 285-305.

Petersen, Mitchell A. and Raghuram G. Rajan. 1994 "The Benefits of Lending Relationships: Evidence from Small Business Data." Journal of Finance, 49, March, 3-38.

Weinstein, David E. and Yishay Yafeh. 1995. “Japan's Corporate Groups: Collusive or Competitive? An Empirical Investigation of Keiretsu Behavior.” Journal of Industrial Economics, 43, December, 359-76.

Weinstein, David E. and Yishay Yafeh. 1998. "On the Costs of a Bank-Centered Financial System: Evidence from the Changing Main Bank Relations in Japan." Journal of Finance, 53, 635-72. 
Table 1

Bonds and Loans as a Percent of Assets, Mean Values

\begin{tabular}{lrrrrrr}
\hline & \multicolumn{2}{c}{ All Firms } & \multicolumn{2}{c}{ Keiretsu Firms } & \multicolumn{2}{c}{ Non-Keiretsu Firms } \\
\cline { 2 - 7 } Bonds & \multicolumn{1}{c}{1995} & 1999 & \multicolumn{1}{c}{1995} & 1999 & 1995 & 1999 \\
\cline { 2 - 7 } Loans & 9.73 & 7.10 & 9.93 & 8.29 & 9.60 & 6.30 \\
Same-Keiretsu Loans & 18.64 & 19.68 & 22.05 & 23.20 & 16.32 & 17.32 \\
Bank Loans & & & 7.12 & 8.09 & & \\
Main Bank Loans & 15.28 & 16.40 & 17.69 & 18.78 & 13.64 & 14.80 \\
Nonbank Loans & 4.65 & 5.37 & 5.08 & 6.07 & 4.36 & 4.90 \\
Government Loans & 1.36 & 1.33 & 1.72 & 1.79 & 1.12 & 1.02 \\
\hline \hline
\end{tabular}


Table 2

Descriptive Statistics for Regressors

\begin{tabular}{lcccc}
\hline \hline \multirow{2}{*}{ KEIR } & Mean & Std Dev & Min & Max \\
\cline { 2 - 5 } PK & 0.509 & 0.500 & 0 & 1 \\
\hline MBLMB & 12.168 & 16.638 & 0 & 88.300 \\
\hline MBLFD & 0.077 & 0.168 & 0 & 1.683 \\
\hline MBPCPR & 7.068 & 6.737 & 0 & 75.265 \\
\hline FROA & -6.381 & 24.471 & -55.915 & 57.783 \\
\hline FLIQA & 2.637 & 2.914 & -18.644 & 24.843 \\
\hline FSALES & 34.365 & 15.475 & 1.230 & 96.079 \\
\hline BPCPR & 0.590 & 10.345 & -49.631 & 152.800 \\
\hline MBANK & -5.246 & 23.423 & -56.358 & 128.835 \\
\hline SAMEK & 0.072 & 0.258 & 0 & 1 \\
\hline FLASSET & 0.061 & 0.239 & 0 & 1 \\
\hline FENBMKT & 7.359 & 1.505 & 2.750 & 11.185 \\
\hline FINBMKT & 0.014 & 0.119 & 0 & 1 \\
\hline FEXBMKT & 0.710 & 0.454 & 0 & 1 \\
\hline \hline
\end{tabular}


Table 3

Factors Affecting the Probability of Increased Bank Lending

Logit Specification

\begin{tabular}{|c|c|c|}
\hline KEIR & $\begin{array}{c}\text { Full Sample } \\
0.062 \\
(0.050)\end{array}$ & $\begin{array}{c}\text { Outliers Eliminated } \\
0.078 \\
(0.054)\end{array}$ \\
\hline PK & $\begin{array}{l}-0.006^{* *} \\
(0.002)\end{array}$ & $\begin{array}{l}-.007 * * \\
(0.002)\end{array}$ \\
\hline MBLMB & $\begin{array}{c}0.032 \\
(0.104)\end{array}$ & $\begin{array}{c}0.177 \\
(0.213)\end{array}$ \\
\hline MBLFD & $\begin{array}{l}0.011^{*} \\
(0.006)\end{array}$ & $\begin{array}{l}0.025^{* *} \\
(0.008)\end{array}$ \\
\hline MBPCPR & $\begin{array}{l}-0.002 \\
(0.001)\end{array}$ & $\begin{array}{l}-0.001 \\
(0.001)\end{array}$ \\
\hline FROA & $\begin{array}{l}-0.050 * * \\
(0.010)\end{array}$ & $\begin{array}{l}-0.056^{* * *} \\
(0.009)\end{array}$ \\
\hline FLIQA & $\begin{array}{l}-0.011^{* *} \\
(0.002)\end{array}$ & $\begin{array}{l}-0.010^{* * *} \\
(0.002)\end{array}$ \\
\hline FSALES & $\begin{array}{l}0.005^{* *} \\
(0.002)\end{array}$ & $\begin{array}{c}0.004 \\
(0.003)\end{array}$ \\
\hline BPCPR & $\begin{array}{c}0.003 \\
(0.003)\end{array}$ & $\begin{array}{c}0.005 \\
(0.003)\end{array}$ \\
\hline MBANK & $\begin{array}{l}0.843^{* * *} \\
(0.098)\end{array}$ & $\begin{array}{l}0.804 * * \\
(0.087)\end{array}$ \\
\hline MB*KSAME & $\begin{array}{l}-0.271 * * \\
(0.101)\end{array}$ & $\begin{array}{l}-0.275^{*} \\
(0.118) \\
\end{array}$ \\
\hline $\mathrm{MB} * \mathrm{FROA}$ & $\begin{array}{l}-0.045^{* * *} \\
(0.009)\end{array}$ & $\begin{array}{l}-0.039 * * \\
(0.009)\end{array}$ \\
\hline MB*FLIQA & $\begin{array}{l}-0.007 * * \\
(0.002)\end{array}$ & $\begin{array}{l}-0.007 * * \\
(0.002)\end{array}$ \\
\hline MB*FSALES & $\begin{array}{l}-0.001 \\
(0.002)\end{array}$ & $\begin{array}{l}-.004 * \\
(0.002)\end{array}$ \\
\hline $\mathrm{MB} * \mathrm{BPCPR}$ & $\begin{array}{l}-0.004 * * \\
(0.001)\end{array}$ & $\begin{array}{l}-.004 * * \\
(0.001)\end{array}$ \\
\hline MB*MBLMB & $\begin{array}{l}0.784 * \\
(0.320)\end{array}$ & $\begin{array}{l}1.132 * \\
(0.495)\end{array}$ \\
\hline $\mathrm{MB} * \mathrm{MBLFD}$ & $\begin{array}{l}0.015^{* * *} \\
(0.006)\end{array}$ & $\begin{array}{l}0.018^{* * *} \\
(0.007)\end{array}$ \\
\hline SAMEK & $\begin{array}{l}0.542^{* *} \\
(0.129)\end{array}$ & $\begin{array}{l}0.554 * * \\
(0.124)\end{array}$ \\
\hline SK*FROA & $\begin{array}{l}-0.005 \\
(0.016) \\
\end{array}$ & $\begin{array}{l}-0.016 \\
(0.012)\end{array}$ \\
\hline SK*FLIQA & $\begin{array}{c}0.001 \\
(0.003)\end{array}$ & $\begin{array}{c}0.001 \\
(0.003)\end{array}$ \\
\hline SK*FSALES & $\begin{array}{l}-0.005 \\
(0.003)\end{array}$ & $\begin{array}{l}-0.003 \\
(0.003)\end{array}$ \\
\hline SK*BPCPR & $\begin{array}{l}-0.007 * \\
(0.003)\end{array}$ & $\begin{array}{l}-0.005 \\
(0.003)\end{array}$ \\
\hline SK*MBPCPR & $\begin{array}{c}0.003 \\
(0.001)\end{array}$ & $\begin{array}{c}0.001 \\
(0.001)\end{array}$ \\
\hline SK*MBLMB & $\begin{array}{c}0.406 \\
(0.373) \\
\end{array}$ & $\begin{array}{c}0.671 \\
(0.552) \\
\end{array}$ \\
\hline SK*MBLFD & $\begin{array}{l}-0.005 \\
(0.005)\end{array}$ & $\begin{array}{l}-0.005 \\
(0.005)\end{array}$ \\
\hline Number of Observations & 81732 & 78711 \\
\hline Log Likelihood & 39383 & 37876 \\
\hline
\end{tabular}

Notes: The estimated equations also include FLASSET, FENBMKT, FINBMKT, FEXBMKT, a set of industry dummy variables, and a set of annual dummy variables. The set of estimated coefficients for secondary banks not in the same keiretsu is the base, with the estimated coefficients for all other types of lenders representing differential effects. Below each estimated coefficient, we report the associated robust standard error calculated by relaxing the assumption of independence of the errors for a given year.

* Significant at the 5 percent level.

** Significant at the 1 percent level. 


\begin{tabular}{lccl} 
Table 4 & & \\
Factors Affecting the Probability of Increased Bank Lending, Categorized by Keiretsu Groups \\
Logit Specification; Omitting Outlier Observations & & \\
\hline \hline & Major Zaibatsu & Minor Zaibatsu & Non-Zaibatsu \\
Intercept & 0.073 & $0.136^{* *}$ & -0.045 \\
& $(0.099)$ & $(0.033)$ & $(0.096)$ \\
\hline KSAME & $0.667^{* *}$ & $0.432^{* *}$ & $0.959^{* *}$ \\
& $(0.124)$ & $(0.118)$ & $(0.309)$ \\
\hline FROA & $-0.042^{*}$ & -0.019 & $0.050^{* *}$ \\
& $(0.018)$ & $(0.021)$ & $(0.018)$ \\
\hline FLIQA & 0.002 & 0.000 & -0.010 \\
& $(0.004)$ & $(0.002)$ & $(0.006)$ \\
\hline FSALES & $-0.005^{* *}$ & -0.001 & 0.006 \\
& $(0.002)$ & $(0.005)$ & $(0.018)$ \\
\hline BPCPR & -0.006 & $0.002^{*}$ & -0.012 \\
& $(0.003)$ & $(0.001)$ & $(0.011)$ \\
\hline MBANK & -0.188 & -0.213 & $-0.764^{* *}$ \\
& $(0.120)$ & $(0.140)$ & $(0.220)$ \\
\hline MBPCPR & $0.006^{* *}$ & $-0.009^{* *}$ & 0.006 \\
& $(0.002)$ & $(0.002)$ & $(0.010)$ \\
\hline MBLMB & -1.109 & 0.965 & $2.997^{* *}$ \\
& $(0.879)$ & $(0.764)$ & $(0.495)$ \\
\hline MBLFD & -0.001 & -0.008 & -0.023 \\
& $(0.006)$ & $(0.012)$ & $(0.023)$ \\
\hline Number of & & 78711 & \\
Observations & & 37849 & \\
\hline Log Likelihood & & & \\
\hline \hline & & & \\
\hline
\end{tabular}

Notes: The estimated equations also include the same set of base and main bank interactive variables included in the Table 1 specification. The set of estimated coefficients for secondary banks not in the same keiretsu is the base, with the estimated coefficients for all other types of lenders representing differential effects. Below each estimated coefficient, we report the associated robust standard error calculated by relaxing the assumption of independence of the errors for a given year.

* Significant at the 5 percent level.

** Significant at the 1 percent level. 


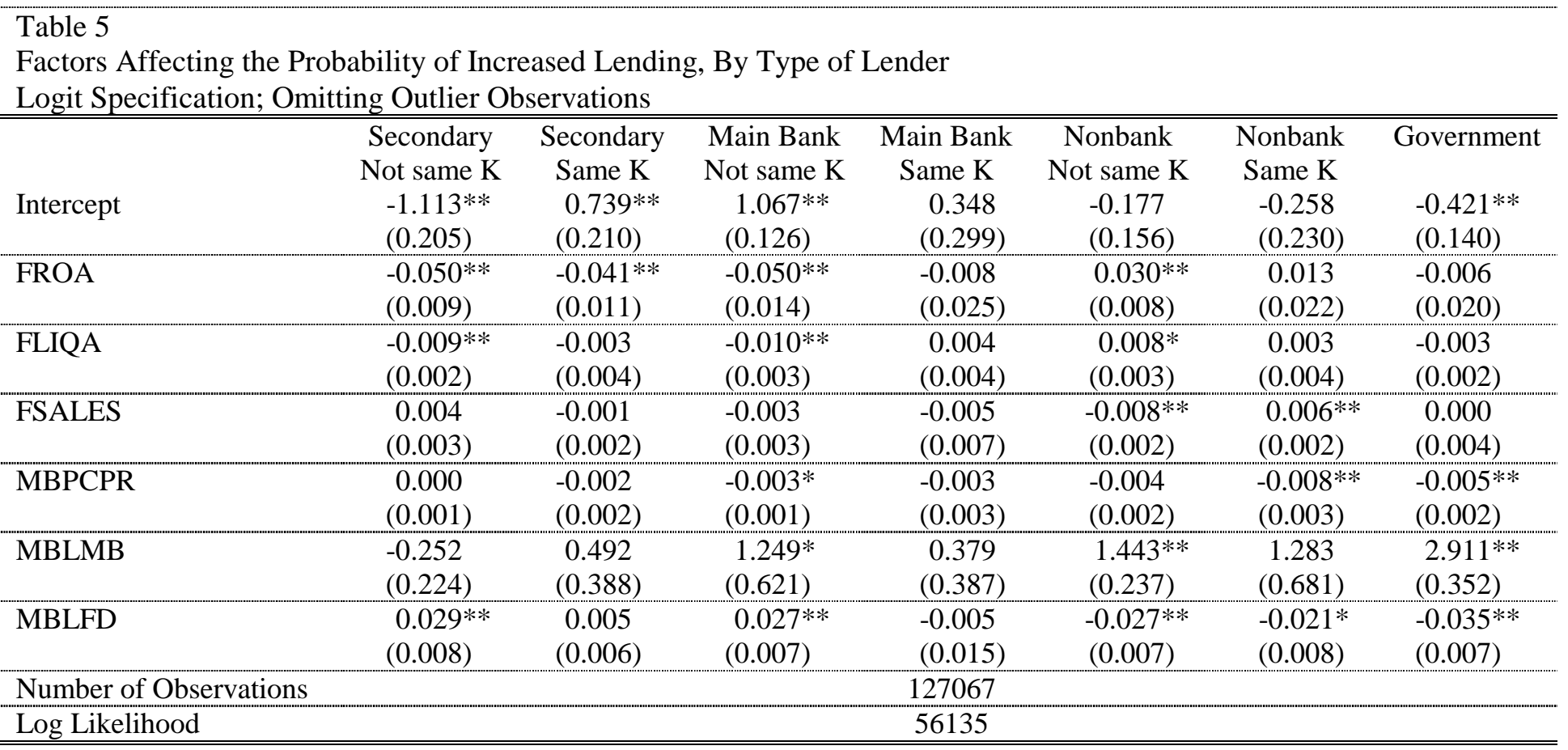

Notes: The estimated equations also include KEIR, PK, FLASSET, FENBMKT, FINBMKT, FEXBMKT, a set of industry dummy variables, and a set of annual dummy variables. The set of estimated coefficients for secondary banks not in the same keiretsu is the base, with the estimated coefficients for all other types of lenders representing differential effects. Below each estimated coefficient, we report the associated robust standard error calculated by relaxing the assumption of independence of the errors for a given year.

* $\quad$ Significant at the 5 percent level.

** $\quad$ Significant at the 1 percent level. 
Table 6

Loan Increases and Stock Prices

\begin{tabular}{lll}
\hline \hline & \multicolumn{1}{c}{$(1)$} & $(2)$ \\
\cline { 2 - 3 } Total Loans & $-1.793^{*}$ & \\
Main Bank & $(0.855)$ & \\
Not Same Keiretsu & & -1.833 \\
Main Bank & & $(1.145)$ \\
Major Zaibatsu & & $-3.868^{* *}$ \\
Main Bank & & $(0.887)$ \\
Minor Zaibatsu & & -0.904 \\
Main Bank & & $(2.304)$ \\
Non-Zaibatsu & & -1.825 \\
Number of Observations & & $(4.664)$ \\
$\mathrm{R}^{2}$ & 3847 & 3847 \\
\hline
\end{tabular}

Notes: Each equation also includes a set of annual time dummy variables and a set of industry dummy variables. Below each estimated coefficient, we report the associated robust standard error calculated by relaxing the assumption of independence of the errors for a given year.

* Significant at the 5 percent level.

** Significant at the 1 percent level. 